\title{
AKSESBILITAS KAMPUS RAMAH DIFABEL
}

\author{
1) Ahmad Zaki, ${ }^{2)}$ Yessi Jusman \\ 1) Program Studi Teknik Sipil, Universitas Muhammadiyah Yogyakarta, 55183 Yogyakarta, INDONESIA \\ 2) Program Studi Teknik Elektro, Universitas Muhammadiyah Yogyakarta, 55183 Yogyakarta, INDONESI \\ E-mail : ahmad.zaki@umy.ac.id,yjusman@umy.ac.id
}

\begin{abstract}
ABSTRAK
Sering kali kita mendengar istilah ramah difabel dilekatkan pada berbagai sarana prasarana maupun layanan publik. Sehingga sering kali pula kita jumpai istilah puskesmas ramah difabel, sekolah atau kampus ramah difabel, kantor pemerintah ramah difabel, dan sebagainya. Salah satu ciri kampus ramah difabel adalah terbukanya dengan luas akses belajar dengan baik, misalnya, tersedianya jalur pedestrian dengan guiding block, ramp (jalan miring) untuk masuk ke sebuah gedung, adanya tangga dengan pegangan tangan (hand-rail), lift dengan tombol huruf braille, dan toilet khusus difabel di setiap gedung. Syarat-syarat mengenai sarana prasarana ramah difabel secara detail telah diatur pada Peraturan Menteri Pekerjaan Umum dan Perumahan Rakyat (PermenPUPR) Republik Indonesia No 14 Tahun 2017. Untuk membangun aksesbilitas yang prioritas bagi mahasiswa difabel UMY akan dilaksanakan beberapa kegiatan seperti survei untuk pendataan mahasiswa difabel Universitas Muhammadiyah Yogyakarta (UMY), diikuti dengan seminar, dan dilanjutkan dengan evaluasi dan sarana prasarana untuk aksesbilitas mahasiswa difabel UMY melalui survei lapangan. Melalui survei tersebut, Gedung kembar AR Fachruddin UMY memang sudah mempunyai akses jalan miring, tangga dengan hand-rail, dan lift dengan tombol huruf braille, namun belum memiliki toilet khusus difabel yang sesuai standar untuk mereka yang mempunyai kebutuhan khusus sesuai PermenPUPR No 14 Tahun 2017 tersebut. Survei juga dilakukan pad Gedung Admisi, Gedung Siti Walida F3, serta jalur pedestrian antara Gedung AR Fachruddin, Gedung Admisi, dan Gedung Siti Walida.
\end{abstract}

Kata Kunci: Difabel, Kampus Ramah Difabel, PermenPUPR

\section{ABSTRACT}

Often we hear the term diffable friendly attached to various infrastructure and public services. So that, we often encounter the terms diffable-friendly health center, diffable-friendly school or campus, diffable-friendly government offices, and so on. One of the characteristics of a disability-friendly campus is that it is open to good access to learning, for example, the availability of pedestrian paths with guiding blocks, ramps to enter a building, stairs with handrails, elevators with letter keys braille, and disabled toilets in each building. The requirements for diffable-friendly infrastructure have been regulated in detail in the Regulation of the Minister of Public Works and Public Housing (PermenPUPR) of the Republic of Indonesia No. 14 of 2017. To build priority accessibility for students with disabilities, UMY will carry out several activities such as a survey for data collection of university students with disabilities. Muhammadiyah Yogyakarta (UMY), followed by a seminar, and followed by evaluation and infrastructure for the accessibility of students with disabilities of UMY through a field survey. Through this survey, the AR Fachruddin UMY twin building already has access to a ramp, stairs with hand-rails, and an lift with braille keys, but does not yet have a special toilet with disabilities that meets the standards for those with special needs according to PermenPUPR No. 14 of 2017 the. The survey was also carried out at the Admissions Building and the Siti Walida Building.

Keyword: Difabel, Disabled-friendly Campus, PermenPUPR

\section{PENDAHULUAN}

Sebagaimana dirilis dalam situs resmi World Health Organization (WHO), difabel adalah kependekan dari different ability. Difabel merupakan istilah dari gangguan atau keterbatasan atau kekurangan pada kemampuan, aktivitas, dan partisipasi. Difabel biasa diistilahkan sebagai orang yang berkebutuhan khusus atau orang kurang upaya $[1,2]$. Data statistik yang dihimpun oleh WHO mempresentasikan bahwa jumlah orang yang berkebutuhan khusus berkisar 15\% dari total populasi penduduk Dunia. Di Indonesia, pada tahun 2011 orang yang berkebutuhan khusus diperkirakan sekitar 15\% dari total penduduk Indonesia atau mencapai 36.15 juta jiwa orang dari total penduduk yang mencapai 241 juta jiwa [3]. Sebelumnya, pada tahun 2004 orang yang berkebutuhan khusus di Indonesia diperkirakan sebanyak 1.480 .000 dengan rincian sebagai 
berikut: penyandang tunadaksa berjumlah 162.800 orang (11\%), tunanetra 192.400 (13\%), tunarungu $503.200(34 \%)$, mental dan intelektual $348.800(26 \%)$, dan orang yang pernah mengalami penyakit kronis (kusta dan tuberklosis) 236.800 (16\%) [4].

Undang-Undang Penyandang Disabilitas No 8 Tahun 2016 dan Undang-Undang Republik Indonesia Nomor 20 Tahun 2003 tentang Sistem Pendidikan Nasional adalah dasar hukum memberikan jaminan sepenuhnya kepada orang yang berkebutuhan khusus dalam menempuh jenjang pendidikan seperti kebanyakan orang yang normal. Meskipun telah banyak Perguruan Tinggi di Indonesia baik negeri maupun swasta yang membuka pintu selebar-lebarnya bagi calon mahasiswa yang berkebutuhan khusus, sarana dan prasarana kampus belum disiapkan dengan baik [5]. Sarana dan prasarana kampus sebagai aksesbilitas bagi mahasiswa yang berkebutuhan khusus dinilai belum ramah dan nyaman bagi mereka. Sesuai dengan Permenristekdikti No. 46 tahun 2017 tentang pendidikan khusus dan pendidikan layanan khusus di Perguruan Tinggi, Perguruan Tinggi berkewajiban menyediakan sarana dan prasarana yang sesuai dengan mahasiswa berkebutuhan khusus. Aksesibilitas dalam Undang-Undang Nomor 4 Tahun 1997 didefinisikan sebagai kemudahan yang disediakan bagi yang berkebutuhan khusus untuk membantu dan memberikan kesempatan mereka dalam segala kegiatan dan aspek kehidupan [6].

Selain peraturan di atas, beberapa fakta juga menunjukkan bahwa calon mahasiswa berkebutuhan khusus yang masuk Perguruan Tinggi, khususnya Universitas Muhammadiyah Yogyakarta (UMY) setiap tahunnya selalu ada. Oleh karena itu, mereka perlu penanganan secara khusus mulai dari proses seleksi, selama masa belajar, dan hingga mereka menyelesaikan studi. Secara fisik, pelayanan terhadap para penyandang disabilitas tentu tak sebatas memberikan bimbingan, namun juga disiapkan sarana dan prasarana kampus yang ramah difabel. Banyak aktivitas dirasa cukup berat bagi mahasiswa difabel seperti bagaimana mereka menuju ke ruang perkuliahan di tingkat atas sementara tidak ada lift dan hanya ada tangga sempit yang juga tidak ada pegangan tangan. Pihak Perguruan Tinggi diharapkan gencar membangun fasilitas atau infrastruktur kampus, seperti pembuatan akses jalan masuk berupa ramp di setiap gedung, dan lain-lain. Beberapa perubahan berupa pembangunan sarana dan prasarana ramah difabel sangat dibutuhkan agar pemenuhan kebutuhan yang berkebutuhan khusus tidak hanya berupa konsep atau teori tanpa aplikasi nyata. Penyediaan sarana belajar, prasarana berupa fasilitas khusus yang mendukung aksesibilitas dan lingkungan sosial yang mendukung adalah suatu yang perlu dioptimalkan untuk mewujudkan kampus yang ramah bagi difabel.

\section{METODE PELAKSANAAN}

Untuk melaksanakan program pengabdian ini, ada beberapa metode pelaksanaan pengabdian yang dilakukan, yaitu:

1. Survei atau Pendataan

Kegiatan pertama adalah survei atau pendataan mahasiswa UMY yang difabel dengan bekerjasama dengan Pusat Studi Disabilitas dan Kemanusiaan UMY. Survei atau pendataan dilakukan dengan menyebarkan google form webinar aksesbilitas kampus ramah difabel melalui Pusat Studi Disabilitas dan Kemanusiaan UMY kepada mahasiswa difabel. Selain pendataan, survei melalui google form juga berisi pertanyaan tentang tiga aksesbilitas prioritas yang harus ada di kampus. Sehingga hasil dari pertanyaan tersebut akan dibahas pada webinar online. 
2. Webinar Online

Karena pandemi covid-19 sehingga cukup beresiko mengadakan seminar offline, webinar dengan term of reference yang sudah disusun sebagai gantinya. Mahasiswa difabel yang terdata pada survei atau pendataan di atas diundang untuk menghadiri webinar online Aksesbilitas Kampus Ramah Difabel. Selain itu, webinar ini juga mengundang asosiasi difabel Yogyakarta dan sekitarnya serta informasi webinar juga disebar secara umum melalui media sosial. Pemateri webinar ini adalah berasal dari Pusat Layanan Difabel UIN Sunan Kalijaga, Pusat Studi Disabilitas dan Kemanusiaan UMY, dan Dosen Prodi Teknik Sipil UMY. Untuk belajar dan mendiskusikan tentang aksesbilitas yang ramah mahasiswa difabel di kampus.

3. Survei Aksesbilitas Kampus Ramah Difabel

Melalui webinar dan diskusi di atas diharapkan bisa menyimpulkan beberapa aksesbilitas prioritas yang sesuai dengan kebutuhan mahasiswa difabel terutama di kampus UMY. Karena setiap mahasiswa difabel akan mempunyai kebutuhan yang hampir sama. Aksesbilitas prioritas yang belum ada diharapkan akan dibangun di beberapa gedung secara bertahap menyesuaikan perencanaan pembangunan UMY. Aksesbilitas tersebut bisa berupa sarana dan prasarana seperti jalur jalan kaki (pedestrian) yang ramah difabel lengkap dengan ramburambu yang dibutuhkan, dilanjutkan dengan akses jalur miring (ramp) menuju ke gedunggedung perkuliahan mahasiswa difabel, toilet khusus mahasiswa difabel di masing-masing gedung, dan lain-lain.

\section{HASIL}

Aksesibilitas merupakan sebuah isu yang selalu diangkat dalam pembahasan mengenai pemenuhan hak khusus para difabel. Berdasarkan undang-undang tersebut di atas, aksesibilitas memang harus diperhatikan dalam usaha pemenuhan hak difabel di lingkungan Perguruan Tinggi. Sehingga aktivitas mahasiswa difabel sejak hadir ke kampus, kuliah, sampai pulang kembali ke rumah atau kos masing-masing tidak terkendala.

Berikut akan diuraikan hasil dan pembahasan dari hasil pelaksanaan program pengabdian masyarakat tentang Aksesbilitas Kampus Ramah Difabel:

1. Pendataan melalui google forms

Peserta yang terdiri dari mahasiswa difabel, akademisi, aktivitis disabilitas, dan masyarakat umum berjumlah 42 orang dengan rincian seperti pada Tabel 1 di bawah ini.

Table 1. Pendataan dan peserta webinar online

\begin{tabular}{clc}
\hline No & Universitas/Institusi/Organisasi & Jumlah Peserta \\
\hline 1 & Universitas Muhammadiyah Yogyakarta & 7 \\
\hline 2 & Universitas Abdurrab & 3 \\
\hline 3 & DPC Gerkatin kabupaten Sleman & 2 \\
\hline 4 & UIN Sunan Kalijaga Yogyakarta & 2 \\
\hline 5 & DPD Gerkatin DIY & 1 \\
\hline 6 & IAIN SAMARINDA & 1 \\
\hline 7 & Idhola (Indonesian Deaf-HoH Law and Advocacy) & 1 \\
\hline 8 & IKIP Saraswati & 1 \\
\hline 9 & Kementerian Sosial & \\
\hline
\end{tabular}




\begin{tabular}{lll}
\hline 10 & LKRM & 1 \\
\hline 11 & PLJ DIY & 1 \\
\hline 12 & Politeknik Pariwisata Makassar & 1 \\
\hline 13 & Pusat Layanan Juru Bahasa Isyarat & 1 \\
\hline 14 & Relawan Nusantara & 1 \\
\hline 15 & STIE Al Khairiyah & 1 \\
\hline 16 & STKIP Kie Raha Ternate & 1 \\
\hline 17 & Telkom University & 1 \\
\hline 18 & Universitas Ahmad Dahlan & 1 \\
\hline 19 & Universitas Gadjah Mada & 1 \\
\hline 20 & Universitas Hasanuddin & 1 \\
\hline 21 & Universitas Jenderal Achmad Yani Yogyakarta & 1 \\
\hline 22 & Universitas Jenderal Soedirman & 1 \\
\hline 23 & Universitas Muhammadiyah Cirebon & 1 \\
\hline 24 & Universitas Muhammadiyah Surakarta & 1 \\
\hline 25 & Universitas Negeri Gorontalo & 1 \\
\hline 26 & Universitas Padjadjaran & 1 \\
\hline 27 & Universitas Pamulang & 1 \\
\hline 28 & Universitas Tanjungpura & 1 \\
\hline 29 & Universitas NU Cirebon & 1 \\
\hline 30 & Universitas Terbuka & 1 \\
\hline 31 & Yayasan Audisi & 1 \\
\hline 32 & Yayasan Transfigurasi Tabor Mulia (YTTM) & 42 \\
\hline & & Total
\end{tabular}

2. Webinar online

Acara webinar online dibuka oleh Pak Budi Santoso, S.Psi, M.KM selaku Koordinator Divisi Pengurangan Resiko Bencana (PRB) Muhammadiyah Disaster Management Centre (MDMC) Beliau menyampaikan tentang Konsepsi Pengurangan Resiko Bencana MDMC Muhammadiyah yang berpihak pada Inklusi dan Disabilitas, penyampaiannya bisa dilihat pada link: https://youtu.be/UvN-aahxOgY. Beliau menyampaikan kegiatan ini sesuai dengan Mandat Muktamar ke-47 Muhammadiyah di Makassar agar peran mitigasi dan advokasi bencana pada satuan pendidikan sangat penting, terkhusus pada 20.000 lebih satuan pendidikan muhammadiyah, sehingga menjadi penting bagi kita bersama bagaimana aksesbilitas itu bisa mengadvokasi layanan yang ramah pada kaum difabel. Dengan UMY membuat role model fasilitas ramah difabel bisa jadi akan diduplikasi oleh satuan pendidikan muhammadiyah dan satuan pendidikan yang lain. Ada tiga materi yang disampaikan pada webinar ini, yaitu:

a. Materi 1 tentang Fasilitas bagi Disabilitas di UIN Sunan Kalijaga oleh Bu Rof'ah, Ph.D dengan link: https://youtu.be/VgeQOz-64-s

b. Materi 2 tentang Hak Fasilitas bagi Disabilitas oleh Bu Dr. Arni Surwanti dengan link https://youtu.be/Ouvhrn0ThME

c. Materi 3 tentang Fasilitas Ramah Difabel oleh Ahmad Zaki, Ph.D: dengan link https://youtu.be/KVW5ausDt6A

d. Dan diakhiri dengan diskusi dapat dilihat pada link: https://youtu.be/r0998Ac0ee4 


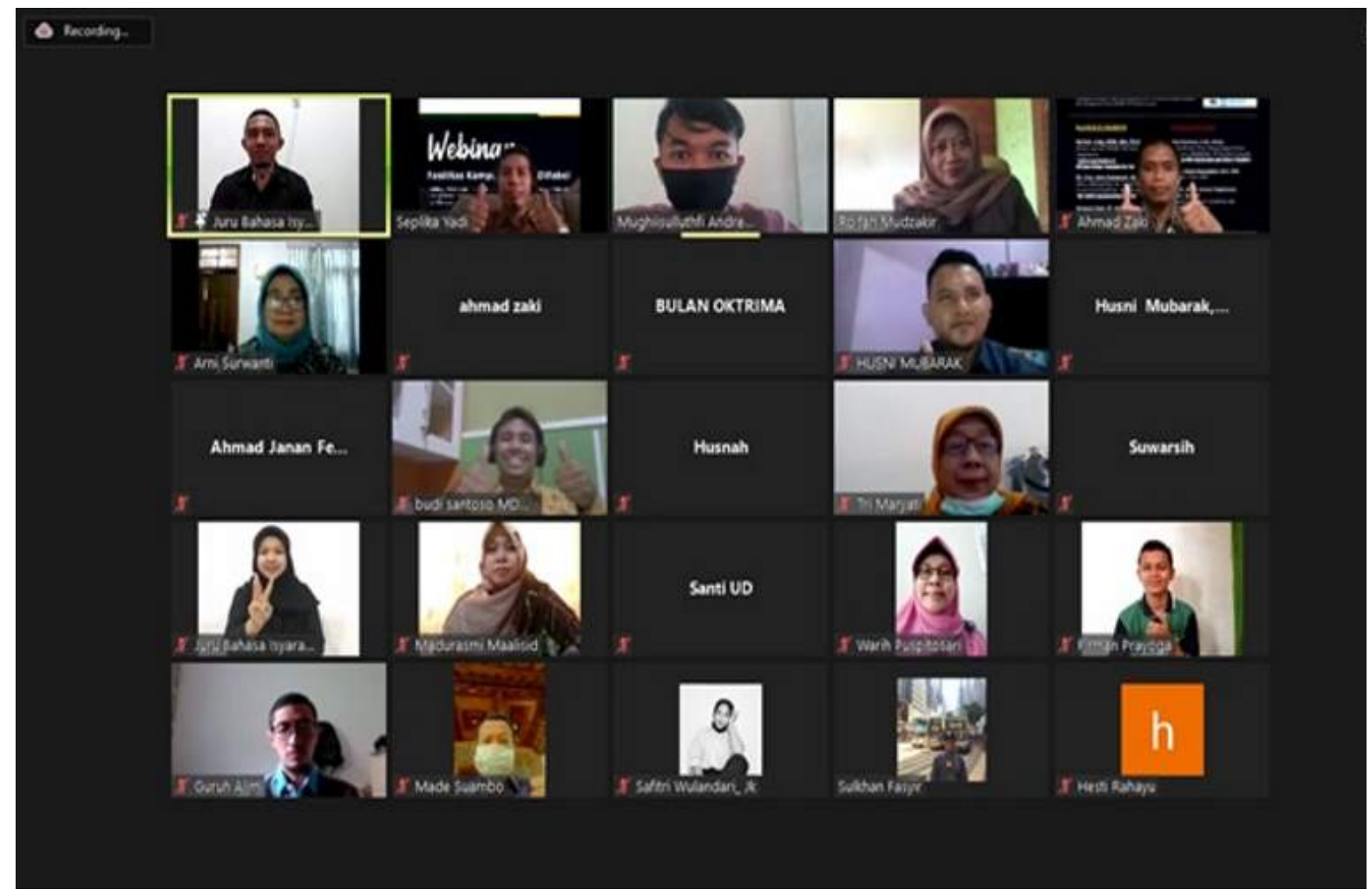

Gambar 2. Dokumentasi Webinar Online

3. Survei aksesbilitas kampus UMY

Aksesbilitas kampus yang disurvei adalah pada Gedung AR Fachruddin, Gedung Admisi, dan Gedung Siti Walida F3 seperti yang digambarkan pada Gambar 2.
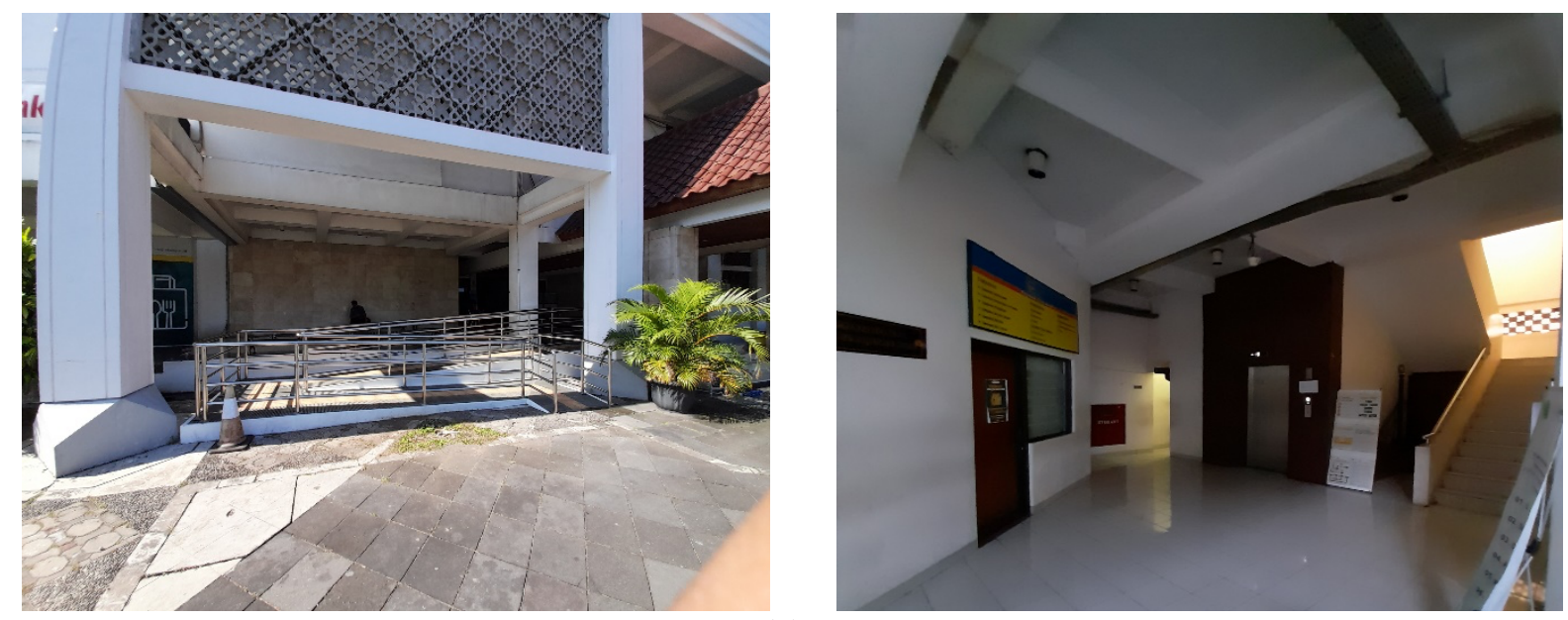

(a) 

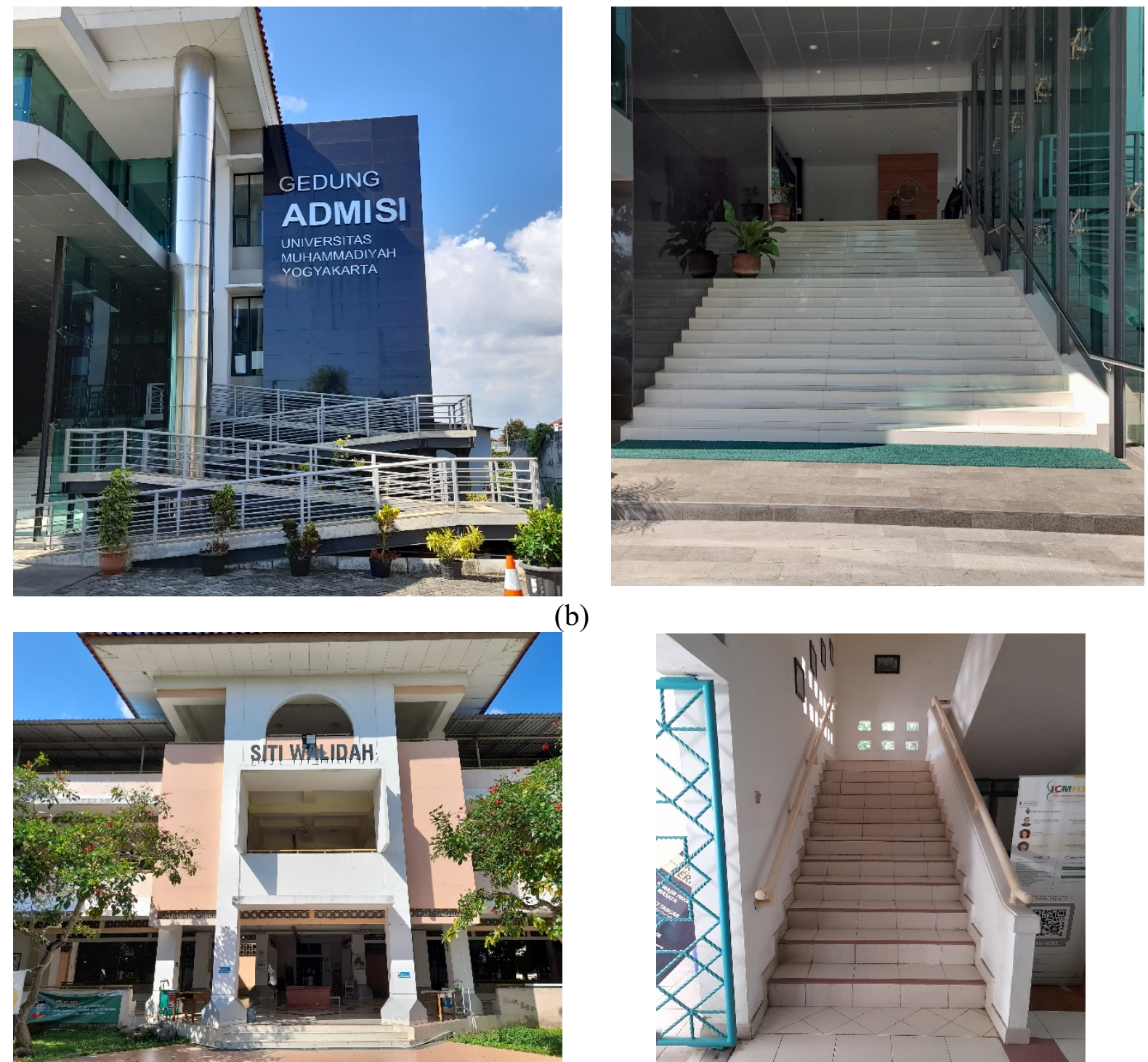

(b)

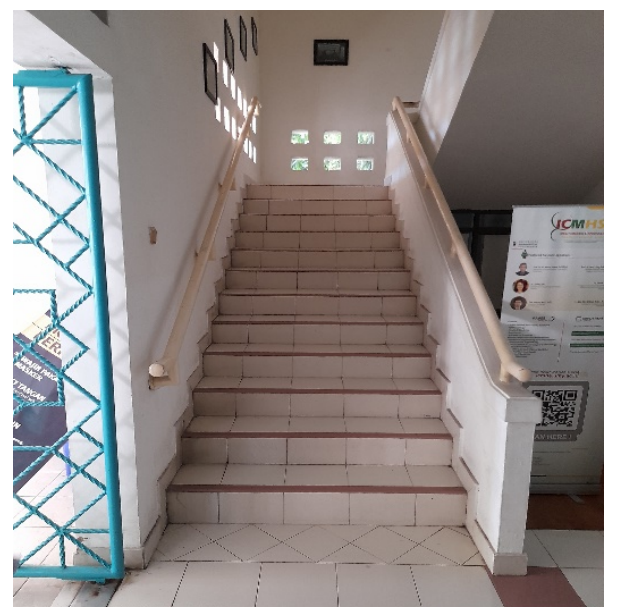

[6]

Gambar 2 (a) Gedung AR Fachruddin, (b) Gedung Admisi, dan [6] Gedung Siti Walida

Berdasarkan PermenPUPR No 14 tahun 2017 dan hasil quisioner berupa google forms telah dirumuskan beberapa aksesbilitas kampus ramah difabel yaitu:

a. Pintu

Menurut pasal 11 ayat 1 PermenPUPR No 14 Tahun 2017, pintu adalah merupakan bagian dari tapak, bangunan atau ruang sebagai sarana untuk masuk dan keluar yang pada umumnya dilengkapi dengan penutup.

b. Selasar

Menurut pasal 12 ayat 1 PermenPUPR No 14 Tahun 2017, selasar adalah merupakan jalur sirkulasi di luar Bangunan Gedung yang tidak dibatasi oleh dinding atau dibatasi paling banyak oleh 1 (satu) sisi dinding.

c. Koridor

Menurut pasal 13 ayat 1 PermenPUPR No 14 Tahun 2017, koridor adalah merupakan jalur sirkulasi di dalam atau di luar Bangunan Gedung yang dibatasi oleh 2 (dua) sisi dinding.

d. Jalur Pemandu 
Menurut pasal 15 ayat 1 PermenPUPR No 14 Tahun 2017, koridor berfungsi sebagai jalur sirkulasi bagi Penyandang Disabilitas netra termasuk penyandang gangguan penglihatan yang hanya mampu melihat sebagian yang terdiri atas ubin pengarah dan ubin peringatan.

e. Tangga

Menurut pasal 18 ayat 1 PermenPUPR No 14 Tahun 2017, tangga merupakan sarana transportasi vertikal manual bagi pejalan kaki yang dirancang dengan mempertimbangkan kemiringan, ukuran pijakan, dan ketinggian anak tangga yang sesuai sehingga nyaman dan aman untuk digunakan oleh seluruh penggunanya.

f. Ramp

Menurut pasal 19 ayat 1 PermenPUPR No 14 Tahun 2017, ramp merupakan jalur sirkulasi yang memiliki bidang dengan kemiringan dan lebar tertentu untuk memudahkan akses antarlantai bagi Penyandang Disabilitas dan/atau Pengguna Bangunan Gedung dan Pengunjung Bangunan Gedung.

g. Lift

Menurut pasal 20 ayat 1 PermenPUPR No 14 Tahun 2017, lift merupakan alat mekanis elektrik untuk membantu pergerakan vertikal di dalam Bangunan Gedung.

Berdasarkan survei meskipun mungkin belum semua, sejumlah tempat di beberapa kampus telah memiliki beberapa aksesbilitas ramah difabel prioritas seperti yang dirangkumkan pada Tabel 2. Pada tabel tersebut gedung yang cukup memiliki aksesbilitas ramah difabel yang cukup baik di gedung AR Fachruddin.

Tabel 2. Evaluasi aksesbilitas Kampus Ramah Difabel berdasarkan PermenPUPR No. 14/2017

\begin{tabular}{|c|c|c|c|c|c|}
\hline No & $\begin{array}{c}\text { Jenis } \\
\text { Aksesbilitas }\end{array}$ & $\begin{array}{c}\text { PermenPUPR } \\
\text { No. } 14 / 2017\end{array}$ & $\begin{array}{c}\text { Gedung } \\
\text { AR } \\
\text { Fachruddin } \\
\end{array}$ & $\begin{array}{l}\text { Gedung } \\
\text { Admisi }\end{array}$ & $\begin{array}{c}\text { Gedung } \\
\text { Siti Walida }\end{array}$ \\
\hline $\mathrm{A}$ & Hubungan $\mathrm{H}$ & orizontal & & & \\
\hline \multirow[t]{3}{*}{1} & Pintu & a. Lebar minimal $92 \mathrm{~cm}$ & Lebar $98 \mathrm{~cm}$ & Pintu otomatis & Lebar $145 \mathrm{~cm}$ \\
\hline & & $\begin{array}{l}\text { b. Tinggi pegangan } \\
\text { pintu } 110 \mathrm{~cm} \text { dari } \\
\text { permukaan lantai }\end{array}$ & Tinggi $110 \mathrm{~cm}$ & Pintu otomatis & $\begin{array}{l}\text { Tinggi } 110 \\
\mathrm{~cm}\end{array}$ \\
\hline & & $\begin{array}{l}\text { c. Pegangan pintu tidak } \\
\text { licin dan bukan tuas } \\
\text { putar }\end{array}$ & ya & Pintu otomatis & ya \\
\hline \multirow[t]{3}{*}{2} & Selasar & $\begin{array}{l}\text { a. Lebar minimal } 140 \\
\mathrm{~cm}\end{array}$ & Lebar $300 \mathrm{~cm}$ & - & Lebar $300 \mathrm{~cm}$ \\
\hline & & $\begin{array}{l}\text { b. Dilengkapi dengan } \\
\text { petunjuk arah }\end{array}$ & tidak & - & tidak \\
\hline & & $\begin{array}{l}\text { c. Ada pegangan (hand- } \\
\text { railing) di salah satu } \\
\text { sisi }\end{array}$ & tidak & - & tidak \\
\hline \multirow[t]{2}{*}{3} & Koridor & a. Lebar minimal $92 \mathrm{~cm}$ & Lebar $250 \mathrm{~cm}$ & Lebar $157 \mathrm{~cm}$ & Lebar $166 \mathrm{~cm}$ \\
\hline & & $\begin{array}{l}\text { b. Dilengkapi dengan } \\
\text { petunjuk arah }\end{array}$ & tidak & tidak & tidak \\
\hline
\end{tabular}




\begin{tabular}{|c|c|c|c|c|c|c|}
\hline & & & $\begin{array}{l}\text { Ada pegangan (hand- } \\
\text { railing) di salah satu } \\
\text { sisi. }\end{array}$ & tidak & tidak & tidak \\
\hline $\mathrm{B}$ & Hubung & ertil & & & & \\
\hline \multirow[t]{9}{*}{1} & \multirow[t]{9}{*}{ Tangga } & a. & $\begin{array}{l}\text { Tinggi anak tangga } \\
\text { tidak } 15-18 \mathrm{~cm}\end{array}$ & Tinggi $19 \mathrm{~cm}$ & Tinggi $15 \mathrm{~cm}$ & Tinggi $17 \mathrm{~cm}$ \\
\hline & & b. & $\begin{array}{l}\text { Lebar anak tangga } \\
\text { paling sedikit } 30 \mathrm{~cm}\end{array}$ & Lebar $30 \mathrm{~cm}$ & Lebar $30 \mathrm{~cm}$ & Lebar $30 \mathrm{~cm}$ \\
\hline & & c. & $\begin{array}{l}\text { Menggunakan } \\
\text { material yang tidak } \\
\text { licin }\end{array}$ & ya & ya & ya \\
\hline & & d. & Kemiringan tangga & Kemiringan & Kemiringan & Kemiringan \\
\hline & & & umum $<35^{\circ}$ & $30^{0}$ & $30^{0}$ & \\
\hline & & e. & $\begin{array}{l}\text { Dilengkapi pegangan } \\
\text { (hand-rail) yang } \\
\text { menerus }\end{array}$ & ya & ya & ya \\
\hline & & f. & $\begin{array}{l}\text { Dilengkapi dengan } \\
\text { penanda huruf braille }\end{array}$ & tidak & tidak & tidak \\
\hline & & g. & Jumlah anak tangga & Anak tangga & Anak tangga & Anak tangga \\
\hline & & & $\begin{array}{l}\text { sampai dengan } \\
\text { bordes (landing) } \\
\text { paling banyak } 12 \\
\text { anak tangga }\end{array}$ & 12 & 12 & 12 \\
\hline \multirow[t]{6}{*}{2} & \multirow[t]{6}{*}{ Ram } & a. & $\begin{array}{l}\text { Memiliki kelandaian } \\
<60^{\circ} \text { di dalam } \\
\text { bangunan }\end{array}$ & - & - & - \\
\hline & & b. & Memiliki kelandaian & Kemiringan & Kemiringan & - \\
\hline & & & $\begin{array}{l}<50^{\circ} \text { di luar } \\
\text { bangunan }\end{array}$ & $45^{0}$ & $40^{0}$ & \\
\hline & & c. & $\begin{array}{l}\text { Lebar efektif } 95 \mathrm{~cm}- \\
120 \mathrm{~cm} \text { tanpa dan } \\
\text { dengan tepi } \\
\text { pengaman }\end{array}$ & Lebar $105 \mathrm{~cm}$ & Lebar $105 \mathrm{~cm}$ & - \\
\hline & & d. & $\begin{array}{l}\text { Dilengkapi dengan } \\
\text { ubin peringatan }\end{array}$ & Ada & Ada & - \\
\hline & & e. & $\begin{array}{l}\text { Dilengkapi dengan } 2 \\
\text { pegangan (hand-rail) } \\
\text { yang menerus di } \\
\text { kedua sisi dengan } \\
\text { ketinggian } 80 \mathrm{~cm}\end{array}$ & $\begin{array}{l}\text { Ada dengan } \\
\text { tinggi } 90 \mathrm{~cm}\end{array}$ & $\begin{array}{l}\text { Ada dengan } \\
\text { tinggi } 88 \mathrm{~cm}\end{array}$ & - \\
\hline \multirow[t]{3}{*}{3} & \multirow[t]{3}{*}{ Lif } & a. & $\begin{array}{l}\text { Lebar lobi paling } \\
\text { sedikit } 185 \mathrm{~cm}\end{array}$ & Lebar $300 \mathrm{~cm}$ & - & Lebar $300 \mathrm{~cm}$ \\
\hline & & b. & $\begin{array}{l}\text { Panel lif bagian luar } \\
\text { dipasang dengan } \\
\text { ketinggian maksimal } \\
90 \mathrm{~cm} \text { dari muka } \\
\text { lantai bangunan }\end{array}$ & $\begin{array}{l}\text { Tombol } 123 \\
\mathrm{~cm}\end{array}$ & - & Tinggi $90 \mathrm{~cm}$ \\
\hline & & c. & $\begin{array}{l}\text { Dilengkapi dengan } \\
\text { panel huruf braille }\end{array}$ & ada & - & tidak \\
\hline
\end{tabular}




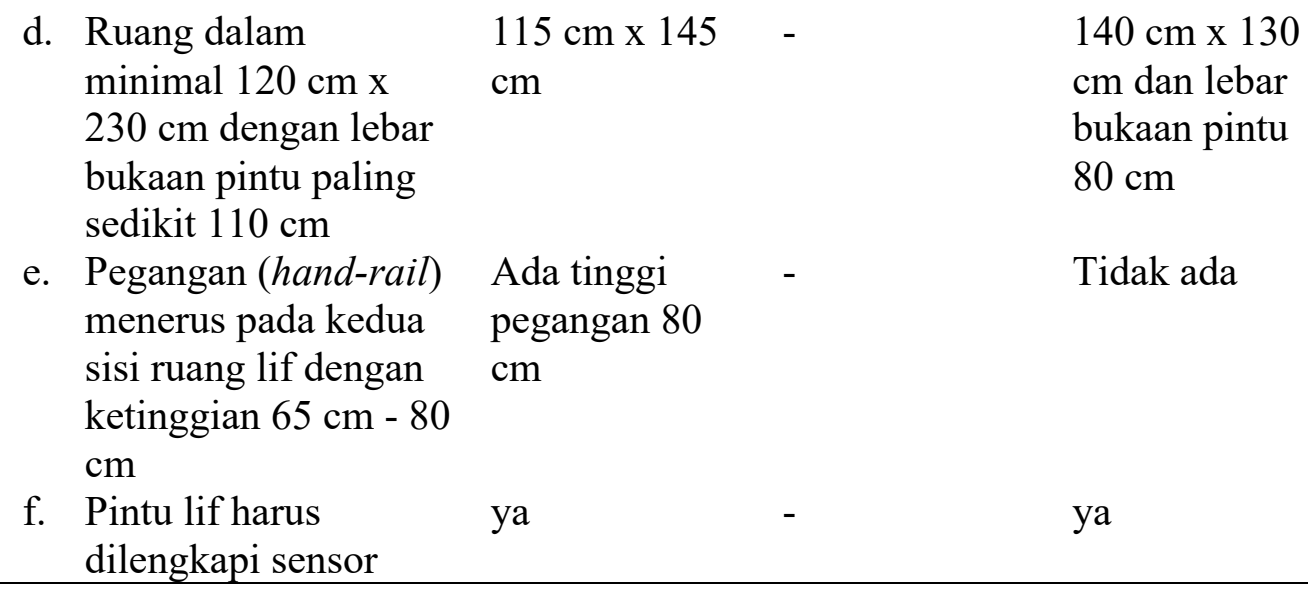

\section{KESIMPULAN}

Berdasarkan analisis kegiatan program kemitraan masyarakat "Aksesbilitas Kampus Ramah Difabel" dapat disimpulkan sebagai berikut:

1. Kegiatan pengabdian pada masyarakat yang dilakukan ini sangat bermanfaat dalam meningkatkan pengetahuan peserta yang terdiri dari akademisi, mahasiswa difabel, aktivis difabel, dan masyarakat umum dalam hal aksesbilitas atau penyediaan sarana dan prasarana kampus yang ramah difabel.

2. Pengabdian pada masyarakat tentang aksesbilitas kampus ramah difabel untuk akademisi, mahasiswa difabel, aktivis difabel, dan masyarakat umum berupa webinar online sangat perlu karena setiap kampus harus mempersiapkan sarana dan prasarana kampus yang ramah difabel karena pada esensinya menurut PermenPUPR tentang persyaratan kemudahan bangunan Gedung adalah setiap pengguna dan pengunjung bangunan Gedung seperti yang berkebutuhan khusus gedung memiliki hak yang sama untuk dapat mengakses dan menjalankan aktivitasnya dalam bangunan Gedung dan lingkungan secara aman, nyaman, mudah, dan mandiri. Sehingga setiap bangunan harus didesain secara universal, yaitu rancangan bangunan gedung dan fasilitasnya yang dapat digunakan oleh semua orang tanpa terkecuali (maupun yang berkebutuhan khusus) secara bersama-sama tanpa diperlukan adaptasi atau perlakuan khusus.

3. Pengabdian pada masyarakat tentang aksesbilitas kampus ramah difabel juga berupa survei sarana dan prasarana beberapa bangunan gedung di UMY seperti Gedung AR Fachrudin yang merupakan pusat aktivitas administrasi dan banyak Bank, Gedung admisi karena merupakan pintu masuk mahasiswa baru, dan Gedung Siti Walida F3 yang merupakan pusat kegiatan belajar mahasiswa sebagai evaluasi kesiapan kampus ramah difabel.

\section{UCAPAN TERIMA KASIH}

Penulis mengungkapkan ucapan terima kasih kepada sejumlah pihak yang berkontribusi dalam mensukseskan pelaksanaan kegiatan pengabdian ini, antara lain:

1. Lembaga Penelitian, Publikasi dan Pengabdian Masyarakat (LP3M) Universitas Muhammadiyah Yogyakarta yang telah mendanai kegiatan pengabdian masyarakat melalui Dana Hibah Program Kemitraan Masyarakat 2020.

2. Muhammadiyah Disaster Management Center (MDMC) melalui Koordinator Divisi Pengurangan Resiko Bencana, Pak Budi Santoso, S.Psi, M.KM.

3. Pusat Studi Disabilitas dan Kemahasiswaan UMY sebagai mitra pengabdian yang telah membantu pelaksanaan kegiatan dari awal sampai selesai.

4. Program Studi Teknik Sipil yang telah memfasilitasi pelaksanaan kegiatan ini.

5. Bu Rof'ah dari UIN Sunan Kalijaga dan Bu Arni Surwanti dari UMY yang telah memberikan 
materi tentang disabilitas di kampus pada acara Webinar Fasilitas Kampus Ramah Difabel.

\section{DAFTAR PUSTAKA}

[1]. Widinarsih D, "Penyandang Disabilitas di Indonesia: Perkembangan Istilah dan Definisi," Vol. 20, No. 2, pp. 127-142, Okt. 2019

[2]. Setyaningsih R and Gutama T A, "Pengembangan Kemandirian bagi Kaum Difabel (Studi Kasus pada Peran Paguyuban Sehati dalam Upaya Pengembangan Kemandirian bagi Kaum Difabel di Kabupaten Sukoharjo)," Vol. 31, No. 1, pp. 42-52, April 2016

[3]. Syafi'ie M, "Pemenuhan aksesibilitas bagi penyandang disabilitas," Vol. 1, No. 2, pp. 269308, Des. 2014

[4]. Julaeha S, "Evaluasi Aksesibilitas Bagi Penyandang Tunadaksa Di Fakultas Ilmu Pendidikan Universitas Negeri Yogyakarta", Program Studi Teknik Sipil dan Perencanaan, Yogyakarta, 2019

[5]. Jefri T, "Aksesibilitas sarana dan prasarana bagi penyandang tunadaksa di Universitas Brawijaya," Vol. 3, No. 1, pp. 16-25, Juli 2016

[6]. Bachtiar Y B, "Evaluasi Aksesibilitas Bagi Penyandang Tunanetra Dan Tunadaksa Terhadap Elemen Aksesibilitas Gedung Lembaga Pengembangan Dan Penjaminan Mutu Pendidikan Universitas Negeri Yogyakarta", Program Studi Teknik Sipil dan Perencanaan, Yogyakarta, 2019 